\title{
ETHICS AND ECONOMICS IN THE WORLD OF GLOBALIZED FINANCE*
}

\author{
Umberto Triulzi**
}

Received: 8.3 .2020

Review

Accepted: 10. 4. 2020

DOI 339.9:17

DOI https://doi.org/10.30924/mjcmi.25.s.8

\begin{abstract}
The paper analyzes the reasons that led, in the years following the nineteenth century, to a vision of economic phenomena distant from ethics. After a brief introduction on the meaning of the concept of economics in the ancient world, the article describes which factors contributed most to developing an image of human behaviour, motivated only by perfect rationality, self-interest, wealth maximization, showing the reasons that have separated economics and finance from ethics. The paper then deals with the theme of how to bring finance closer to the real economy, starting from the need to

final part describes the initiatives, promoted by the EU for the development of the Capital Market Union and the instrument recently introduced by the EU to develop finance long-term investments, the ELTIFs. In the conclusion, we present a proposal for the creation of a new innovative asset class, the Infrastructure Mortgage Backed Security, for the promotion of investments in infrastructures, responding to the needs of investors and requiring business models, based on shared ethic values and on the responsibility of all the agents, working inside and outside the companies.
\end{abstract} search for solutions capable of producing radical changes in the business models of companies and in the financing investments, aimed at maximizing social inclusion and collective well-being. The

Keywords: ethics, economics, finance, economic growth, securities.

\section{INTRODUCTION}

The theme of ethics and economics has always been the centre of attention and study of those, who had the objective of interpreting the principles and rules, historically guiding the human action, e.g., philosophers, historians, sociologists, economists. A relationship was made even more complicated by the difficulties of reconciling rationality and economic efficiency with the moral constraints and ethical objectives, both individual and collective, that the

institutions need for the proper functioning of the economic system and for the governance of the organizations or communities where they operate. In the last two decades, the ethical-economic debate has resumed a more conflicting form, with accents that distance the possibility of finding convergence towards shared values and objectives of sustainable economic development, with the defense of justice and equality in the distribution of wealth on a global, national and local level. The first part of the

\footnotetext{
* This research was carried out within the Erasmus+ Programme of the European Union in the framework of Strategic Partnership project "Cultural Studies in Business" (ERASMUS 2018-1-IT02-KA203-048091). The paper reflects only the views of the authors, and the European Commission cannot be held responsible for any use, which may be made of the information contained therein.

** Umberto Triulzi, PhD, Professor of Economic Policy, Sapienza University of Rome, Department of Political Sciences, Piazzale Aldo Moro 5, 00185, Rome, Italy, E-mail: umberto.triulzi@uniroma1.it, ORCID: https://orcid. org/0000-0003-3219-7293
} 


\section{Journal of Contemporary Management Issues}

article, after a brief historical reconstruction of this relationship in the philosophical and economic thought, developed at the end of the $19^{\text {th }}$ century, analyzes the main reasons that led to an increasing separation between ethics and economics. In the second part, the attention is directed to highlighting the consequences, induced by the financial crisis of the years 2007-2008. This crisis not only materially and ethically accentuated the distances between economy from equity and social justice, but also contributed to spreading a distorted and unrealistic image of the behaviour of homo oeconomicus. In the third part, recalling the results of a study, carried out on the acquisition of the financial resources needed to get Italy out of the crisis of low growth and debt (Leonetti and Triulzi, 2018), an alternative financial approach, aiming to build a space for sharing interests and responsibilities and reconciling labour and capital with ethics and social values is presented.

\section{ETHICS AND ECONOMICS}

We start with a question, raised by many well-known economists, anthropologists and political scientists (Keynes, 1924; Simon, 1977; Sen, 1987; Polanyi, 2001; Appadurai, 2016). Can economic science be useful in interpreting the main ethical values of life and finding solutions that respect ethics? Following John Maynard Keynes (Keynes, 1924: 321-322), a good economist must be "a mathematician, historian, statesman, philosopher - in some degree. He must understand symbols and speak in words. He must contemplate the particular in terms of the general and touch abstract and concrete in the same flight of thought. He must study the present in the light of the past for the purposes of the future. No part of man's nature or his institutions must lie entirely outside his regard. He must be purposeful and is interested in a simultaneous mood; as aloof and incorruptible as an artist, yet sometimes as near to earth as a politician." Very enlightening words still today. It is the integration of different scientific knowledge that allows the economist to interpret life, not only in terms of the variables that determine its evolution (income and its distribution, labour, capital) but as an "ethical value" that each branch of science, from medicine, biology, physics, mathematics, to economics, must safeguard by making its scientific contribution (Urry, 2005; Castellani and Hafferty 2009; Freedman, 2014; Kirman, 2016).

It may be interesting to remember how already in Aristotle's the Nicomachean Ethics ( $4^{\text {th }}$ century BC), there was a vision of the economy linked to the evaluation and advancement of fundamental objectives, among which "the human good", a desirable goal for the single person, and, as he expresses himself, "more beautiful and more divine if it concerns a people and cities". Hence the link with ethics and with the ethical conception of politics. A concept based on the search for the ultimate goal of human actions, the meaning of life and the values that make it alive and worth living.

The birth of the modern economy in the $18^{\text {th }}$ century is attributed to a moral professor at the University of Glasgow, the author of The Wealth of Nations, Adam Smith (1723-1790). According to Smith, citizens and economic operators, through labour specialization and trade, pursue not only selfish interests but a "common feeling", considering themselves citizens of the world, members of a community they are happy to sacrifice their personal interest for. As claimed by Amartya Sen in Ethics and Economics (1987), Adam Smith's wellknown passage in which he refers to the butcher, brewer and baker is often quoted: 
"It is not from the benevolence of the butcher, the brewer, or the baker that we expect our dinner, but from their regard to their own interest. We address ourselves, not to their humanity but to their self-love, and never talk to them of our own necessities but of their advantages".

Less attention has been given to Smith's writings on economy and society, on the ethical analysis of human feelings and behaviour, on the conditions of poverty. Development, according to Sen, is not "the improvement of the wealth of the economy in which human beings live but the improvement of the richness of human life".

Philosophical and economic thinking developed in the years following the eighteenth century, from utilitarianism, to Marxian analysis, marginalism, Keynesian theories, the economics of well-being, monetarism, neo-liberalism, will lead the modern economy away from normative economics, which studies economic phenomena as they should be, to positive economics, which studies and describes the causal relationships between economic variables, with the aim of predicting their progress in the future, ending to ignore the ethical considerations that underpin, and in fact influence, human behaviour (Triulzi 2018).

The reasons that highlight the most the separation between ethics and economics are many. However, looking at the most recent years, some events have contributed more than others to define and spread an image of human behaviour, dominated by rationality, self-interest, selfishness, with no interest in altruism, empathy, civic sense, ethics (Stiglitz, 2010). In particular, to summarize as much as possible the debate between ethics and economics that has lasted for centuries and, indeed, has not yet been concluded, four main reasons and empirical events may explain the lower attention given to ethical issues and spreading an image of the human behaviour distorted from reality.

\subsection{The ideology of the market}

The first is ideological, the construction of an economic thought developed in recent centuries, which places at the centre of its analysis a man, whose sole interest and goals are the accumulation of material goods. The forces of the market, with their pricing mechanism (the price paid for an asset is a good indicator of the usefulness that people derive from its use), private initiative and the increase in productivity are the factors that ensure the improvement of citizens' living conditions. The conditions of poverty and inequality in income levels, which are present in both the least developed and the most advanced countries, can be mitigated, if the economy is left free to achieve its objectives, the growth of wealth. Numerous empirical studies, supported by greater availability of data and more sophisticated quantitative methodologies, have refuted the existence of these conditions (Soman 2004; Milanovic 2012; Mazzuccato and Jacobs 2017). In the wake of the recent crisis, the hypotheses of perfect information, agents' rationality, efficient prices and a natural tendency towards partial or general equilibrium models, which the economic market models are based on, were shown to underestimate the scale and variety of interactions, induced by the financial turmoil and the complexity of the global economy. Markets do not converge towards an equilibrium, but reflect very different and distant economic realities. The most widespread forms of the market are that of an imperfect competition; economic agents have heterogeneous behaviour; individuals are not rational beings and make decisions based on uncertainty and asymmetric 


\section{Journal of Contemporary Management Issues}

information (Hidalgo and Hausmann, 2009; Kirman, 2011; Freedman, 2014). In Kirman's words, individuals, banks, financial agents and intermediaries "were not aware that their increasing interdependent positions were generating a threat to the stability of the whole system. The system was organizing itself but this self-organisation was not stabilizing" (Kirman, 2011: 5). The recent crisis of 2007-2008 has highlighted all the limits and contradictions of the economic-financial model prevailed in recent decades. There are no "free" markets, businesses and consumers belong to profoundly different political and economic systems and do not engage in similar behaviour. Hence, the impossibility of dictating "rules" and applying conventional "economic policies" which everyone, public institutions, enterprises and private citizens, must abide to (Leonetti and Triulzi, 2016). The solution to imperfect markets, characterized by negative externalities is not only the use of public policies to correct market failures, but to rethink the function of the economy and the behaviour of its main actors (institutions, companies, consumers) in terms of ethical values and shared objectives and not only economic needs (Hillman, 2008; Inglehart and Welzel, 2008; Mazzuccato, 2013, 2017; Stiglitz, 2016).

The economy works in a very ineffective manner when market forces generate production imbalances and income inequalities, worsening the welfare and living conditions of many citizens. However, also if independent institutions and courts do not apply justice, citizens' rights are systematically disregarded, essential social services (schools, health services, social security, transport, security and defence) not guaranteed or managed adequately, public policies are aimed at defending the interests of some and not all people (Rawls, 1971). Many countries live in the absence of conditions, capable of ensuring a satisfactory quality of life. Numerous empirical studies in the economic and political field have highlighted that the economy works best in countries where the values mentioned (justice, rights, democracy) are rooted in the behaviour of public institutions and where the civic sense, respect for the rules and citizens' confidence prevail (Hilman, 2008; Rodrik, 1997; Inglehart and Welzel 2005; Kaufmann et al., 2005).

\subsection{The growth of inequalities}

The growth of inequalities represents one of the primary limits of the mainstream economic models. Economic growth and the spread of knowledge, as supported by the existing economic theory, have not helped to reduce inequality. On the contrary, the richest always get rich, in particular those who hold capital incomes, to the detriment of those who live on labour (Piketty, 2014). The consequences of inequalities on the economic and social system are devastating: internal demand is reduced, the richpoor range widened, educational opportunities and the provision of adequate health services lowered, different forms of opposition and violent protests spread and people without real alternatives forced to emigrate. Inequality destroys opportunities, encourages short-term speculation and moves ethics away from the economy (World Bank, 2005; Sachs, 2005; Stiglitz, 2012).

From the recently published World Inequality Report (WIR, 2018), the following information on income and wealth inequality at the global level is drawn. Inequality has increased in most of the countries, but at different speed, suggesting that inequality performance may be due to different national institutions and policies, in terms of trade liberalization, financial regulations, tax systems, educational, 
gender, and wage-setting policies. In 2016, the richest decile, in terms of national income share, owned $37 \%$ of wealth in Europe, $41 \%$ in China, $46 \%$ in Russia, $47 \%$ in North America and around 55\% in subSaharan Africa, Brazil and India. The peak was recorded in the Middle East countries, with $61 \%$. Despite the income growth of the poorest from 1980 , the $1 \%$ richest in the world captured twice as much growth as the bottom $50 \%$, while for middle income people (between the bottom $50 \%$ and top $1 \%$ ) growth has been slow or even zero. A further explanation of the inequality raised by WIR is capital ownership. Over the past few decades, there has been a decrease in public presence in the economy, compared to the strong increase in private wealth, and the financial crisis of 2007-2008 worsened this trend. In 1970, private equity in rich countries was between 200 and $350 \%$ of national income, today is between 400 and $700 \%$. In a word, private capital has increased, but public capital has fallen, with the consequence of lower resources available to fight inequality and prevent further increase.

The trends in inequalities reveal another gap, becoming more and more relevant, as focus is moved from policies aimed toward reducing inequalities in income and basic capabilities and promoting access to essential services (better education and health life), toward more ambitious policies, addressed to reduce divergences in enhanced capabilities. Those should guarantee a full participation of people in the society in the next decades and include access to quality services, resilience to climate shocks, clean energy, and artificial intelligence (UNDP, 2020).

Remarkable progress has been reached in reducing poverty, but not enough has been done to reduce inequalities in basic and enhanced capabilities. Policy-makers can do a lot to fight inequalities through higher taxation on financial income, lower taxation on the labour factor, increasing investment in social sectors, in science and technology, in transport, in communication and education. The national and international political commitments, as evidenced by the achievement of the 2030 Agenda on Sustainable Development (UN, 2019), show that the globalized community is committed to reaching ambitious goals in providing more opportunities to human development in their countries. A lack of resources, wealth concentration, low income inclusion, social and political conflicts, weak leadership, environmental vulnerability, climate damage, prevent it to move faster in this direction.

\subsection{The ideology of finance}

The third factor comes from the different roles that the finance has played in the economy over the past years. The traditional intermediation function, performed by banks in managing savings and granting loans to economic operators was abandoned. The "originate-to-hold- model" that played an extraordinary role in allocating financial resources to support growth and civil well-being, has been replaced by the "originate-to-distribute-model", where banks, in order to expand loans, began to distribute and transfer risks to non-banking institutions, in particular collateralized loan obligations and investment management institutions. Modern finance has grown rapidly, within a system, profoundly changed by innovation, characterized by the entry of new financial intermediary institutions, the excessive use of leverage, the absence of effective regulatory structures of financial supervision. The change in the financial support to real economy became dramatically evident in the last years of the 1990s, when 


\section{Journal of Contemporary Management Issues}

the world financial crisis involved many Far East growing economies, as well as important countries, such as Brazil, Argentina, and Russia.

The economy has always been subject to negative economic cycles, then why the 2007-2008 financial crisis is considered by many specialists to be different from all others? The main reason can be found in the impact of finance in the evolution of the main macroeconomic variables (Roubini, 2010; Krugman, 2009; Adir, 2011; Wieland, 2015). The term "financialization of the economy" precisely describes this phenomenon. We discovered that the neoliberal principles, dominating the economic scene of the 1980s and 1990s, such as deregulation of markets, liberalization of capital movements and privatization of public goods and services, made the financial system more unstable, less predictable in its dynamics, unable to assess the risks of the financial assets, further contributing to its undermining of the economy and its dialectical relationship with ethics (Singer, 2009; Hendry, 2013). Especially with the opening of the markets to short and very short-term capital movements, the end of legislation, related to separation of commercial and investment banks, initially introduced in 1933, by the Glass-Steagall Act, the abolition of the prudential rules, introduced after the bank failures and the crisis of 1929, the situation was radically changed. Finance has been transformed in recent years from activities to assist the process of capital accumulation and to develop entrepreneurial innovation and business growth, into an activity-oriented to itself, rather than toward the interests of its end-users (Montalbano and Triulzi, 2012).

The consequences of the global financial crisis are very well known: banks and intermediary financial industry over-invested in real estate-related products, took excessive risks across the board, created opaque risky securitizations and derivatives. The governments and central banks intervened by injecting huge amounts of liquidity into the economy. The strategy that guided the intervention of the states simply has been to transform private into public debt, avoiding the financial collapse of insurance companies and the credit system, with the hope that the economy would restart. The replacement of public debt with private debt worsened the finances of all advanced countries, especially of the most indebted EU countries, putting the costs of the crisis on the weakest categories: taxpayers and workers (Hillman, 2008; Roubini, 2010; Kay, 2016)

The reaction to the economic and financial crisis, due the excesses of the stock market (speculation, insider trading, unauthorized transactions, and misuse of customer funds) has given rise to a growing demand for more binding rules. Several approaches, dealing with ethical problems have been implemented in finance, ranging from the establishment of ethical codes for professionals (financial advisers, investment companies, brokers, accountants) to the strengthening of the supervisory power of national and international regulatory agencies (BIS, 2010). More ethical initiatives are borne in the banks and business area. Cooperative banks, ethical funds, ethical banks, micro-finance and social bonds are the financial tools introduced to increase the availability of funds for small and medium-sized enterprises. Ethical certification systems are also spreading around the corporate social responsibility programs, with the commitment to preserve sustainability and community welfare (Borzaga, Becchetti 2010, Clarke 2012). 
The specific rules and standards, introduced to observe general moral principles and ethical values in the sphere of economic and financial activities, also shared by international organizations (World Bank, UN, OECD, EU), institutional investors and business organizations are a necessary condition to let the solidarity and reciprocity become the framework of ethical business. But this condition is not sufficient. More principles and ethical guidelines need to be added, starting from a different interpretation of profits, freeing this goal from the pressure of speculation and the obsession with the "short term" that leads to neglect sustainability and the survival of the companies in the long term (Sabatini, 2010; Hendry, 2013). In this context, finance too must change its role, be less linked to highrisk speculative activities and closer to the needs of the operators. A second condition is the sharing of the shareholders' interests with those of the company stakeholders, i.e. workers, suppliers, customers. The ethics of work and business is the foundation of cooperation in the company and equitable sharing of the benefits for the whole community. Globalization, accentuating competition, have made the economic system even more complex, but, as experienced today through the economic and pandemic crisis, without solidarity between countries and between workers and entrepreneurs, the future, in terms of economic security and defense of social and civil rights, becomes increasingly uncertain and insecure. The third condition is linked to what is called intergenerational responsibility. The well-being of the present generation must not compromise the quality of life and growth opportunities of future generations. Therefore, the prudent use of human and natural resources to protect the environment. should be the primary task of political classes, scientists, economic and financial operators. All these moral principles and conditions have to become the guidelines of the economic and social behaviour, if investors, society's interests and stakeholders intend to provide and support business activities where to exercise moral values and ethical commitments (de Bruin, 2015).

The fourth element is the inadequate evaluation of the value of natural capital, represented by the richness of nature and its ecological cycles. The main error, made by the dominant economic ideology was to consider economic growth, supported by technological innovation, as a process that could rely on almost inexhaustible natural resources (Brandt et al., 2013; Raworth, 2018). This belief has led the use of production and consumption systems that have heavily polluted the natural environment, as the emission of toxic products into the atmosphere, water pollution, the introduction of waste and polluting substances into the soil. Only recently, perhaps from the report commissioned by the Club of Rome in 1972 to a group of scientists calling for "the limits of development", have we started to understand the damage caused to the environment by an economic and cultural model that has exploited natural capital, ignored the problems of the ecosphere and altered the ecological cycles. There are still many people, the supporters of infinite growth, who believe that technology is always able to find solutions to the lack of resources, but there are outnumbered by those, who ask for sustainable growth, capable of preserving the planet's resources for future generations (UN, 2015; IRENA, 2020).

The stress produced by humanity on the environment is well described by the UN Environment Programme (Our Planet, 2017). From 1950 to today, the urban population has gone from 746 million inhabitants to 4 billion; the temperature of the earth's surface has grown by $1.1^{\circ} \mathrm{C}$ in the 


\section{Journal of Contemporary Management Issues}

last 20 years; around $40 \%$ of the world's agricultural area has been seriously degraded; almost $80 \%$ of the world's fish areas have been overfished; by 2025, two out of three people in the world will live in areas affected by water scarcity. The Earth, according to geologists, is over 4 billion years old and homo sapiens has inhabited it for a few hundred thousand years, but the damages, inflicted on the planet Earth in the last 50 years are dramatic.

The economy of the common goods intends to take ethics and the defence of natural heritage as values to ensure the creation of more equitable and eco-sustainable societies. Mazzuccato and Jacobs, in their book Rethinking Capitalism (2016), have helped us to understand that public policy is not called only to "correct" market failures but rather to transform, with the energy revolution and the help of new information technologies, the environmental problem into economic opportunities: to stimulate energy saving, encouraging producers and consumers to develop a culture of reuse; to develop public-private partnerships for the promotion of long-term investments in strategic infrastructures; to help create fair distribution and social well-being. Most of the answers we need are there, does politics listen to them and behaves accordingly?

\section{TOWARDS A RADICAL CHANGE IN THE DOMINANT ECONOMIC PARADIGM}

To answer this final question, let us start with two considerations, widely shared by single operators, investors and public institutions. The distortions observed in the economic development of the last 30 years, and even more the consequences produced by the financial crisis of 2007-2008, place the urgency of a profound cultural and ethical renewal in the economic and social dynamics, ensuring greater importance to distributive and social justice and introducing innovative solutions to correct the imbalances, induced by the evolution of the markets. If we look at the dynamics of the global economy, especially during the low growth years, the least valorised factor of production, in many advanced, emerging and developing countries, is the labour of billions of people, decidedly marginalized and underpaid (ILO, 2018). In order to face the complexity of global phenomena, but also the workers' requests, business models of companies must necessarily be reorganized, by innovating and opening themselves towards medium and long-term growth solutions that are economically and socially more sustainable (Freeman, 2012).

To cope with these changes, huge tangible and intangible investments are needed to improve the quality of human capital, to develop the technical and organizational knowledge induced by innovation, to encourage the recruitment of new management models in companies. This is the task of democracy, which should ensure that the economic process, generating growth is directed, through the support of efficient institutions managing public goods and services, to promote the maximization of collective well-being and social inclusion, instead of allowing wealth to belong to an ever smaller number of individuals (World Bank, 2015; Raworth, 2018).

The second consideration is linked to the main problem the real economy is facing today, particularly in the most indebted countries, of how to finance growth, without necessarily increasing public debt. Financing economic growth should rely on long-term investments, capable of improving the production capacity and competitiveness of public and private firms. To 
overcome the constraints, induced by the limited resources available in the countries with heavy debt and high interest to pay for it, it becomes necessary to attract the interest of financial operators with yieldproviding assets. Many sectors offer positive investment opportunities, starting from the environment, energy, climate change technologies and eco-innovation, industrial and service plants, but also social and urban infrastructure, transport and communication infrastructures, education and R\&D. The infrastructure networks represent the backbone of the real economy, the engine of national and local development (Stewart, 2010; OECD, 2015; Fransen, Del Bufalo and Reviglio, 2018; OICU-IOSCO, 2018). These material and immaterial networks allow people, businesses, and families to exchange goods, services, ideas, to move within and outside the country and to continuously spray and feed the economic development. An economic system does not progress enough when these infrastructures, distributed throughout the national territory, are incomplete or inefficiently managed from the technical, financial and managerial points of view.

Physical infrastructures and networks represent channels through which the productive and service sectors of a modern economy are nourished. Returning to invest in these sectors means restoring vitality, efficiency and mobility to all operators with positive spill-over effects on economic growth and employment, starting from the energy sector, which presents promising prospects for investors, but also concrete benefits for consumers (Triulzi, 2018).

According to estimates, reported by the OECD (2017), global infrastructure investments in the sectors of transport, production, transmission and distribution of electricity, water and telecommunications should amount to 6.3 trillion per year, over the 2016-2030 period (95,000 billion of US dollars), a figure equal to $3.5 \%$ of annual world production for the next 15 years.

We know that the issue of long-term investment financing is at the heart of the agendas of the economic policy authorities of the developed countries. The G20, the central banks and the OECD have been engaged for over three years in a work of moral suasion, analysis, study and direction towards the choices of national political decision-makers, and in particular of the economic governance of the European Union, as well as the regulators, to activate a bridge between finance and real economy. However, the results achieved so far are not encouraging.

Financial commitments of the size, reported by the OECD, require not only the joint participation of private and public investors, but also a new business model for financial operators, commercial banks and large insurance companies. It should be built on an innovative approach, capable of simultaneously addressing the necessary harmonization of rules and procedures in the fields of bankruptcy laws, taxes, investor protection, and market infrastructures (Rossi, 2015).

Therefore, new rules are needed, both of a prudential and accounting type, as well as related to different instruments of financial asset management. A path of financial innovation, which ensures the right profits for investors, the correct risk assessment and which, at the same time, gives life to a new economic democracy built on social responsibility and the elimination of the conflict between capital and labour. To achieve this objective, it is necessary to develop an innovative model of participation of capital in the life of companies, but also the participation of workers in the capital and profits 


\section{Journal of Contemporary Management Issues}

of companies, through the involvement of pension and insurance investments in risk capital and in the corporate governance.

\section{A NEW PATH OF FINANCE FOR GROWTH ${ }^{1}$}

The objective of this section is to describe a new financial asset class, addressed to long-term investments that may restore confidence to investors and promote a new phase of growth.

The idea is to borrow the best of the experience of the Asset-Backed Securities $(A B S)$, making it negotiable, transferable and compatible with the fixed income rules, tracing a path of innovation that starts with the financial education of investors and a new interaction between finance and real economy. The European Union, especially the member states of the EMU, are committed to moving budgetary policies in the direction of reducing net and public debt. The Capital Market Union is what the EU intends to develop to stimulate investments, making easier for companies and start-ups to have access to finance and strengthening banking capacity to support the single market project (EC, 2015, 2016).

The Member States are implementing macroeconomic policies, aimed at stimulating higher growth, but the structural deficits of their public finances condition the promotion of employment support policies. The growth of economies with more generous fiscal policies, while ensuring the sustainability of public finances, does not seem easily achievable (OECD, 2020).

\footnotetext{
The paragraph is inspired by the results of a research carried out by the author and Gianfranco Leonetti on the financing of Italy's public debt, edited in Democrazia e Crescita (Eurlink, 2018).
}

Furthermore, as a consequence of the financial crisis, procedures to downsize banks' assets (due to the presence of high non-performing loans) have started, and the three main guidelines have been traced to find resources to be used for investments: the relaunch of bank credit, the promotion of non-bank finance and the more efficient use of public resources.

The Green Paper, The long-term financing of the European economy, presented by the European Commission as early as March 2013, clearly highlighted how "long-term loans contribute to the formation of long-term capital, which includes tangible and intangible assets" (EC, 2013).

Many countries in Europe have also developed investment promotion tools, capable of intervening on a stable basis in entrepreneurial activities, including the use of the National Promotional Banks (EC, 2015).

To start a path of financial innovation that ensures the right profit for investors, the correct assessment of risks and, at the same time, respect for social responsibility, it is necessary to develop the capital market that brings business activity closer, not only to credit institutions, but to investors.

States and international institutions must continue to innovate their entrepreneurial function, ensuring the strategic nature of interventions and protecting general interests, abandoning, as mentioned, the growth model, driven solely by debt and promoting the use of private capital in the real economy. For this to happen, finance must promote a new financial asset - a negotiable, evaluable, transparent and straightforward to use as a container for financing new infrastructures (Leonetti, Triulzi 2016). 
The European Long Term Investment Fund (ELTIF) is an example of an innovative financial instrument, a patient capital catalyst and central instrument of the investment plan for Europe (European Fund for Strategic Investments, EFSI). ELTIFs, by definition, are alternative EU investment funds, managed directly by an alternative investment fund operator (AIFM), authorized under the Directive 2011/61/EU and also designed as an investment vehicle through which the European Investment Bank (EIB) may provide funding for European infrastructure or SMEs. The ELTIFs, however, are not able to become protagonists in the financial markets on their own, which are, as already highlighted, "complex dynamic models", due to the presence of many agents, interacting and influencing each other.

To give the decisive momentum and to remove the mistrust and suspicion that still lingers in the financial markets, support to this innovative financial instrument is needed. The fund managers, even if they evaluate the interventions in infrastructures with less confidence, especially in the presence of a globally standardisable model of Public-Private Partnership (PPP), will not massively enter this new financial asset, if they consider it illiquid and full of regulatory pitfalls and laws.

The ECB, understanding the importance of this financial instrument for the improvement of the bank credit market, has grasped the need to overcome the distrust of ABS with the "Asset Purchase Program" of 2015, including high-standing securitized products in the list of securities eligible as collateral in the context of refinancing operations (Asset-Backed Securities Purchase Program, ABSPP). Since 2015, the European Banking Authority has recommended the introduction of lower capital requirements for high-quality ABS. In 2015, the Basel Committee introduced a comprehensive revision of the regulatory framework, defining the criteria of homogeneity, simplicity and transparency (STC) that the securitization transactions must comply with (BIS, 2015, 2017).

The European legislator, in line with the principles of the Basel Committee, approved the Regulation (EU) 2017/2401, relating to prudential requirements for credit institutions and investment firms, which defines the substantial elements of an overall framework on securitizations, providing criteria for identifying simple, transparent, and standardized securitizations (STS).

The conclusion reached, is that securitizations are an essential element for the functioning of the financial markets, as they constitute a useful asset and liability management and efficient means of transferring risk (Attanasio, Fragliasso, Giasi, Manfredonia, 2016; Bank of Italy, 2017).

However, in the context of the relaunch of long-term investments, we believe that it is necessary to support ELTIFs with a new infrastructure-related financial asset, the Infrastructure Mortgage-Backed Security (IM-BS). The IM-BS must follow the criteria, provided by the Basel Committee for banking supervision, in particular for the so-called STC securitizations, and the "eligibility" criteria, defined by the European Central Bank for contracts repo (RepoEligible ECB in List of eligible marketable assets EBA). Besides, IM-BS will have to be assigned a rating. The collateral of the IM-BS will be represented by infrastructures and real assets and the quality of the collateral, covering the securitization transaction, will determine the quality and performance of the securitized security. 


\section{Journal of Contemporary Management Issues}

The activation of securitization processes with Infrastructure Mortgage-Backed Securities would provide significant advantages for long-term investment financing vehicles, including that of having liquidity to be used for new investments (the ELTIFs).

Furthermore, the relaunch of securitizations in long-term investments will promote a deal generation for fund managers and long-term investors, incentivized again to make investments in infrastructures, as they become aware that the risks borne would be reduced, if supported by a new structure of securitizations aimed at infrastructures, with a scoring model, providing a better orientation to the investors, regarding the choices in terms of risk/return. The benefits for banking systems would also be evident, as they would be driven to promote infrastructure investments again and becoming aware of a reduction in capital ratios (Leonetti and Triulzi, 2018).

\section{CONCLUSIONS}

The great challenges that the global economy of the $21^{\text {st }}$ century is facing, macroeconomic imbalances, growing inequalities, technological gap, social conflicts, require the reaffirmation of the ethical values as the basic principles for the well-being and the human development. Responding to these challenges is a priority, if we want to save global stability and pursue sustainable growth. Changing the current rules of economic and financial governance and overturning the dominant ideology of austerity requires political courage, institutional innovations and leadership that are lacking, especially in Europe.

The monetary policies adopted by the ECB and the promotion of non-bank finance, the stimuli and the non-monetary measures introduced to revive credit, as well as the search for a more efficient use of public resources, have only partially found new resources to be used for investments. The presence of negative nominal returns, both for public securities and for bond markets, can induce large financial intermediaries (banks, pension funds, insurance companies, foundations) to find alternative solutions to those currently activated, mainly in the short, very short term, for the use of huge financial resources at their disposal.

The path opened by the OECD, with the establishment of a task force to develop principles for the financing of long-term investments, by the EU - with the introduction of ELTIFs and by the large European banks (ECB, EIB, Banks and Institutes of National Promotion), as well as the establishment of national/regional platforms to bring together funding, capable of relaunching long-term investments, marks the beginning of a financial approach to the real economy, which must be strengthened and accompanied by sustainable investment projects.

It is from here that we must start again. The defence of joint interests, the awareness that building a bridge between the real economy and finance, work to capital, is in everyone's interest. Addressing the problems of a global economy, blocked by the crisis, through the recovery of a dialogue between all the actors, based on shared ethical values and responsibilities, is the task that awaits us and that stimulates the rethinking of business models of financial operators, but also the models for managing the real and financial wealth of workers.

In a period, in which interest rates have been extraordinarily low for too long, and the monetary policy of quantitative easing has shown, in the absence of equally 
effective interventions on the fiscal side, its limits in supporting the economic recovery, a construction site needs to be opened - in Europe and in the world - to build a renewed relationship between finance and the real economy. Of course, we need ethical rules to share, but also the intellectual courage to propose innovative ideas to achieve a new economic humanism.

\section{References}

1. Abadir, K.M. (2011). Is the Economic Crisis Over (and Out)? Review of Economic Analysis. 3 (2), 102-108.

2. AIFMD (2011). Alternative Investment Directive, Directive 2011/61/UE.

3. American Society of Civil Engineers (ASCE) (2013). The 2013 Report Card for America's Infrastructure.

4. American Society of Civil Engineers (ASCE) (2017). The 2017 Report Card for America's Infrastructure.

5. Ania (2017). Il Trattamento degli investimenti in infrastrutture in Solvency II.

6. Appadurai, A. (2016). Banking on Words. The Failure of Language in the Age of Derivative Finance. Chicago: University of Chicago.

7. Arcadis (2016). Third Global Infrastructure Investment Index 2016, Bridging The Investment Gap.

8. Arinaminpathy N., Kapadia S., May R. (2012). Size and Complexity in Model Financial Systems. Bank of England, Working Paper No. 465.

9. Attanasio F.P., Fragliasso I., Giasi F., Manfredonia F. (2016). ABS come possibile strumento di investimento per ottimizzare il profile di rischio-rendimento del Balance-Sheet. IPE Working paper, No. 10.
10. Banca d'Italia (2014). Il finanziamento degli investimenti a lungo termine: iniziative in corso e principali linee di intervento, Occasional Paper.

11. Banerjee, R., Kearns, J., Lombardi, M. (2015). (Why) is Investment Weak? BIS Quarterly Review, March.

12. Bank for International Settlements (2010). Basel III: A global regulatory framework for more reliant banks and banking systems. Basel: Bank for International Settlements.

13. Bank for International Settlements (2014). Criteria for identifying simple, transparent and comparable securitisations. Basel: Bank for International Settlements.

14. Bank for International Settlements (2015). Regulatory Consistency Assessment Programme, (RCAP) Report on risk-weighted assets for counter party credit risk. Basel: Basel Committee on Banking Supervision.

15. Bank for International Settlements (2015). Basel III Monitoring Report. BIS Quarterly Review, March. Basel: Bank for International Settlements.

16. Bank for International Settlements (2015). 85th Annual Report. Basel: Bank for International Settlements.

17. Bank for International Settlements (2016). 86th Annual Report. Basel: Bank for International Settlements.

18. Bank for International Settlements (2016). Revisions to the securitisation framework. Basel: Bank for International Settlements.

19. Bank for International Settlements (2017). Capital treatment for simple, transparent and comparable shortterm securitisations. Basel: Bank for International Settlements. 


\section{Journal of Contemporary Management Issues}

20. Bank For International Settlements (2018). The post-crisis regulatory agenda: What is missing?, speech by Restoy F.

21. Barkley Rosser J. (1999). On the Complexities of Complex Economic Dynamics. Journal of Economic Perspectives. 13(4), 169-192.

22. Ballé, M., Jones, D.T., Chaize, J., Fiume, O.J. (2017). Strategia Lean. Institute Lean Management, Guerini Next.

23. Bencivenga C., D’Ecclesia R., Triulzi U. (2012). Oil Prices and Financial Crisis. Review of Managerial Science. 6, 227-238

24. Borio C., Disyatat P., Juselius M., Rungcharoenkitkul P. (2017). Why so low for so long? A long-term view of real interest rates, BIS Working papers, No 685.

25. Borzaga C., Becchetti L. (2010). The Economics of Social Responsibility: The World of Social Enterprises. Abingdon \& New York: Routledge.

26. Brandt, N., Schreyer P., Zipperer V. (2013). Productivity Measurement with Natural Capital, OECD Economics Department Working Papers, No. 1092.

27. de Bruin, B. (2015). Ethics and the Global Financial Crisis. Cambridge: Cambridge University Press.

28. Buchanan, M. (2013). To Understand Finance, Embrace Complexity. Bloomberg. Retrieved from https:// www.bloomberg.com/opinion/articles/2013-03-10/to-understand-finance-embrace-complexity

29. Carlin, B., Kogan, S., Lowery, R. (2013). Trading Complex Assets. Journal of Finance, 68 (5). 1937-1960.
30. Castellani, B., Hafferty, F.W. (2009). Sociology and Complexity Science: A New Field of Inquiry. Berlin Heidelberg: Springer-Verlag.

31. Clarke, T. (2012). Ethics, Values and Corporate Governance. In BBVA, Values and Ethics for the 21st Century. 513-558. Madrid: BBVA.

32. D'Ecclesia, R., Magrini, E., Montalbano, P., Triulzi, U. (2014). Understanding Recent Oil Price Dynamics: A novel empirical approach, Energy Economics, 46 (S1), S11-S17.

33. De George, R.T. (2012). A History of Business Ethics in Values and Ethics for the 21st Century. Milano: EF Editores.

34. Dobson, J. (1993). The Role of Ethics in Finance. Financial Analysis Journal, 49(6), 57-61.

35. Global Infrastructure Hub (2016). Preliminary Draft Report on the Annotated PPP Risk Allocation Matrices. Sydney \& Torotno: Global infrastructure Hub.

36. Gollier, C., (2015). Long-term savings: the case of life insurance in France, in Financing the economy: new avenues for growth, Financial Stability Review, $n^{\circ} 19$, Banque de France, 129-136

37. European Central Bank (2016). Decision (EU) 2016/948 of 1 June 2016, Office Journal EU. Frankfurt: European Central Bank.

38. European Central Bank (2017). Decision (EU) 2017/103 of 11 January 2017 amending Decision $E C B / 2016 / 948$. Frankfurt: European Central Bank.

39. European Central Bank (2017). Decision (EU) 2017/1359 of 18 May 2017 amending Decision 
EU/2016/948. Frankfurt: European Central Bank.

40. European Commission (2013). Green Paper on the long-term financing of the European economy. Bruxelles: European Commission.

41. European Commission (2018). Final Report of the High-Level Expert Group on Sustainable Finance. Bruxelles: European Commission.

42. European Commission (2015). Green Paper on Building a Capital Markets Union. Bruxelles: European Commission.

43. European Commission (2015). Working together for jobs and growth: The role of National Promotional Banks (NPBS) in supporting the Investment Plan for Europe. Bruxelles: European Commission.

44. European Commission (2016). State of the Union 2016: Strengthening European Investments for jobs and growth. Strasbourg: European Commission.

45. European Economy (2016). Sovereign and banking risks: What policies?, Regulation (EU) 2017 amending Regulation (EU) No 575/2013 on Prudential Requirements for Credit Institutions and Inve0stment Firms. Bruxelles: European Commission.

46. ESPAS (2016). European Strategy and Policy Analysis System, Global Trends to 2030: Can the EU meet the challenges ahead? Espas: Luxembourg.

47. Fransen, L., Del Bufalo, G., Reviglio, E. (2018). Boosting Investment in Social Infrastructure in Europe, Discussion Paper 074. Bruxelles: European Commision and European Association of Long-Term Investors.
48. Freedman, R.S. (2014). Understanding the Complexity of Financial Systems of Systems. New York: NYU Polytechnic School of Engineering,

49. G20 (2017). Hamburg Action Plan. G20.

50. Goetzmann, W.N. (20169. Money Changes Everything: How Finance Made Civilization Possible. Princeton: Princeton University Press.

51. Hendry, J. (2013). Ethics and Finance: An Introduction. Cambridge: Cambridge University Press.

52. Hidalgo, C.A., Hausmann, R. (2009). The Building Blocks of Economic Complexity. PNSA, 106 (26), 10570-10575.

53. Higgins, K. (2013). Financial Whirlpools: A Systems Story of the Great Global Recession. Amsterdam: Elsevier.

54. Hillman, Arye L. (2008). Globalization and Social Justice. The Singapore Economic Review. 53(2), 173-189.

55. ILO (2018). Global Wage Report 2018/19. Geneva: ILO.

56. Inglehart, R., Welzel, Ch. (2005). Modernization, Cultural Change and Democracy: The Human Development Sequence. Cambridge: Cambridge University Press.

57. IRENA (2020). Global Renewables Outlook, Energy Transformation 2050.

58. Kay, J. (2016). Finance is just another industry, BIS Papers No 84.

59. Kaufmann, D., Kraay, A., Mastruzzi, M. (2005). Governance Matters IV: Governance Indicators for 1996-2004, World Bank Policy Research Working 


\section{Journal of Contemporary Management Issues}

Paper 3630. Washington D.C.: World Bank.

60. Keynes, J.M. (2018). The General Theory of Employment, Interest and Money. Houndmills: Palgrave Macmillan.

61. Kirman, A. (2008). Economy as a Complex System. In S. Durlauf \& L. Blume, The New Palgrave Dictionary of Economics, Second Edition. Houndmills: Palgrave Macmillan. 1619-1625

62. Kirman, A. (2011). Complex Economics, Individual and Collective Rationality. Abingdon \& New York: Routledge, 2011.

63. Kotter, P. (2006). Rethinking Capital. Hoboken: Wiley-Blackwell.

64. Krugman, P. (2009). The Return of Depression Economics and the Crisis of 2008. New York \& London: W.W. Norton Company Limited.

65. KPMG (2015). Political agreement reached on the Regulation for European Long-Term Investment Funds (ELTIFs).

66. Landau, J. P. (2013). Deleveraging, long-term finance and the G20 Agenda, Remarks at the BIS-Bank of Russia Seminar Moscow. Bis Paper.

67. Leonetti, G., Triulzi, U. (2016). The Complexity of Finance in a Globalized World, XI European Conference on Social and Behavioral Sciences, Rome.

68. Leonetti, G., Triulzi, U. (2018). Democrazia e Crescita. Roma: Eurlink University Press.

69. Lucas, R.E. (1980). The Death of Keynesian Economics: Issues and Ideas. Chicago: University of Chicago Press.
70. Mantegna, R.N., Stanley H. E. (1999). An Introduction to Econophysics. Cambridge: Cambridge University Press.

71. Mazzuccato, M. (2013). Lo Stato innovatore. Torino: Editori Laterza.

72. Mazzuccato, M., Jacobs M. (2017). Rethinking Capitalism. Totton. Wiley-Backwell.

73. McCauley, J.L. (2004). Dynamics of Markets: Econophysics and Finance. Cambridge: Cambridge University Press.

74. McKinsey Global Institute (2016). Bridging Global Infrastructure Gaps. McKinsey Global Institute

75. Milanovic, B. (2012). Global income inequality by the numbers: in history and now, an overview. Policy Research working paper, no. WPS 6259. Washington DC: World Bank Group.

76. Montalbano P., Triulzi U. (2012). International Economic Policy. Torino: UTET Università.

77. OECD (2015). Finance and Inclusive Growth, OECD Economic Policy Paper, June $n^{\circ} 14$. Paris: OECD.

78. OECD (2015). Mapping of instruments and incentives for infrastructure financing: a taxonomy, Report to G20 Finance Ministers and Central Bank Governors. Paris: OECD.

79. OECD (2017). Technical note on estimates of infrastructure investment needs. Background note to the report Investing in Climate, Investing in Growth. Paris: OECD.

80. OECD (2020). Structural developments in global financial intermediation: The rise of debt and non-bank credit intermediation. Paris: OECD. 
81. OICU-IOSCO (2014). Market-Based Long-Term Financing Solutions for SMEs and Infrastructure, Research prepared for the G20 Finance ministers and Central Banks. Madrid: The International Organization of Securities Commissions.

82. Polanyi, K. (2001). The Great Transformation. Boston: Beacon Press.

83. Rawls, J. (1971). A Theory of Justice. Cambridge: Belknap Press.

84. Raworth, K. (2018). Doughnut Economics: Seven Ways to Think Like a 21st-Century Economist. London: Chelsea Green Publishing.

85. Reinhart, C.M., Rogoff, K. (2009). This time is different. Eight Centuries of Financial Folly. Princeton: Princeton University Press.

86. Rossi, S. (2015). Finance for Growth: A Capital Markets Union, Keynote address at the Rome Investment Forum 2015 "Financing Long-Term Europe", Rome, 11 December 2015.

87. Roubini, N. (2010). Crisis Economics: A Crash Course in The Future of Finance. New York: Penguin Press.

88. Sachs, J. (2005). The End of Poverty: economic possibilities for our time. New York: Penguin Press.

89. Santini, C. (2010). Finanza Etica ed Economia Sociale, paper presentato al Seminario CISL Lecce.

90. Sen, Amartya K. (1977). Rational Fools: A Critique of the Behavioral Foundations of Economic Theory. Philosophy \& Public Affairs, 6(4), 317-344.

91. Sen, A. (1987). On Ethics and Economics. Chichester: Blackwell Publishing.
92. Simon, H. (1977). Administrative Behavior, $3^{\text {rd }}$ edition. New York, NY: The Free Press.

93. Soman, D. (2004). Framing, Loss Aversion, and Mental Accounting. in Koehler, Derek J. and Nigel Harvey (eds.), Blackwell Handbook of Judgment and Decision-Making. Malden, MA: Blackwell Publishing, 379-398.

94. Sorropago, C. (2014). Behavioral Finance and Aged Based Model: the new evolving discipline of quantitative behavioral finance. Technical Report N.13, Sapienza University of Rome.

95. Smith, A. (1852). The Wealth of Nations. London: Nelson and Sons.

96. Stiglitz, J.E. (2012). The Price of Inequality. New York: W.W. Norton \&Company.

97. Stiglitz, J. E. (2016). The New Rules of the Economy. New York: WW Norton.

98. Stewart, J. (2010). The UK National Infrastructure Plan 2010'. European Investment Bank Papers: Public and Private Financing of Infrastructure.

99. The European House-Ambrosetti (2015). Finance for Growth. Milan: The European House-Ambrosetti.

100. The Lauder Institute and Santander Universities 82015). Overcoming the Infrastructure Gap, Globalization Trend Lab. Retrieved from: http://lauder.wharton.upenn.edu.

101. Triulzi, U. (2018). L'etica della laboriosità e l'incidenza della finanza nell'economia. Napoli: Editoriale Scientifica.

102. United Nations (2015). Financing for Development (Addis Ababa 


\title{
Journal of Contemporary Management Issues
}

Action Agenda, Ethiopia). New York: United Nations.

103. United Nations (2017). Our Planet, UN Environment Programme. New York: United Nations.

104. United Nations (2019). The Sustainable Development Goals Report. New York: United Nations.

105. Urry J. (2005). The Complexities of the Global. Theory, Culture \& Society, 22(5), 235-254.

106. Voora, V.A., Venema H.D. (2008). The Natural Capital Approach, A Concept Paper. Winnipeg, Manitoba: International Institute for Sustainable Development (IISD).

107. Wieland, O.L. (2015). Modern Financial Markets and the Complexity of Financial Innovation, Universal Journal of Accountings and Finance, 3(3), 117 - 125

108. World Bank (2006). World Development Report 2006: Equity and Development. Washington, DC: World Bank.

109. World Bank (2015). Global Financial Development Report 2015-2016: Long-term Finance. Washington, D.C.: The World Bank.

\section{ETIKA I EKONOMIJA U SVIJETU GLOBALIZIRANIH FINANCIJA}

\author{
Umberto Triulzi
}

\begin{abstract}
Sažetak
U radu se analiziraju razlozi koji su, u godinama nakon devetnaestog stoljeća, doveli do promatranja ekonomskih fenomena iz gledišta udaljenih od etike. Nakon kratkog uvoda o značenju pojma ekonomije u drevnom svijetu, članak opisuje koji su čimbenici najviše pridonijeli razvoju slike ljudskog ponašanja koje je motivirano samo savršenom racionalnošću, vlastitim interesima, maksimizacijom bogatstva, te pokazuje razloge koji su razdvojili ekonomiju i financije od etike. Članak se zatim bavi pitanjem kako približiti financije stvarnom gospodarstvu polazeći od potrebe za traženjem rješenja koja mogu proizvesti radikalne promjene u poslovnim modelima poduzeća te u financiranju ulaganja usmjerenih na maksimizaciju socijalne uključenosti i kolektivne dobrobiti. Završni dio članka opisuje, s jedne strane, inicijative koje promiče EU, a usmjerene su ka razvoju tržišta kapitala Unije te, s druge strane, instrument koji je EU nedavno uvela u svrhu razvoja financiranja dugoročnih ulaganja, $t j$. ELTIF (eng. The European Long Term Investment Fund), odnosno Europski dugoročni investicijski fond. U zaključku donosimo prijedlog za stvaranje inovativne klase imovine, Infrastructure Mortgage Backed Security, s ciljem promicanja ulaganja u infrastrukturu koja odgovara potrebama investitora $i$ zahtijeva razvoj poslovnih modela temeljenih na zajedničkim etičkim vrijednostima i odgovornosti svih agenata koji rade unutar i izvan tvrtki.
\end{abstract}

Ključne riječi: etika, ekonomija, financije, ekonomski rast, vrijednosnice 